\title{
Checklist of Aquatic Oligochaetes Species in Tigris-Euphrates River basin
}

\author{
Haifa J. Jaweir*
}

Received 23, April, 2014

Accepted 30, June, 2014

\begin{abstract}
:
A total of 60 species of aquatic oligochaetes were identified in different sites within Tigris-Euphrates basin / Iraq, including River Tigris, River Euphrates, Southern marshes ( Al-Haweiza, Al-Hammar and Al-Chebaiesh ), Shutt Al-Germa, and Shatt Al-Arab. In River Euphrates 39 species were identified, 40 species from River Tigris and 32 species from Shatt-Al-Arab and southern marshes.

The identified species were classified as four species of Family Aeolosomatidae, 54 species of Naididae ( 31 Naidinae , 8 Pristininae and 15 Tubificid worms), one species of each of Lumbriculidae ( Lumbriculus variegates ) and Lumbricidae ( Eiseiella tetraedra).
\end{abstract}

Among Aeolosomatidae, Aelosoma aquaternarium, A. Liedyi, A. variegatum and A. hemprichi, in which, A. variegatum was the most frequent species, found in Euphrates river.

Naidinae community were represented by five species of genus Chaetogaster, two species of each of Paranais, Slavina, \& Stylaria, four species of Allonais, and seven species of each of Dero and Nais, in addition to Stephensoniana trivandrana, Specaria josinae and Ophidonais serpentina. Nais variabilis was the most abundant and frequent species in River Tigris while Stylaria lacustris \& Ophidonais serpentina are abundant in River Euphrates . Species of Pristininae were representative by four species of genus Pristina and three species of genus pristinella, among them Priatina longiseta is the most abundant species.

Tubificid worms, Branchuira sowerbyi and Limnodrilus hoffmeisteri were the most frequent and abundant species in the surface sediments of Iraqi waters. Beside $L$. hoffmeisteri, other five species of Limnodrilus, two species of Potomothrix, and a single species of Tubifex tubifex, Embolocephalus velutinus, Aulodrilus piguetia, Psammoryctides moravicus and Rhyacodrilus coccineus were recorded.

\section{Key words: Aquatic Oligochaetes; Tigris; Euphrates River basin}

\section{Introduction:}

Oligochaeta is a subclass of Class Clitellata, Phylum Annelida, They are predominantly an aquatic and terrestrial class,. The aquatic oligochaetes are placed in two superorders, Megadrili., which are relatively large worms related to earthworms, and Microdrili are mostly smaller, thin-bodied worms without any close terrestrial relatives.

About 1700 valid species of aquatic oligochaetes are known to date, ; of these about 1,100 are freshwater. The most diverse group is the Tubificidae with more than 1,000 described species including 582 being considered as freshwater inhabitants. More than 60 species of megadriles are also considered aquatic [1]. Three families in the orders Tubificida and Lumbriculida are common in freshwater, the Naididae, Lumbriculidae, and Enchytraeidae, in addition to the minor families,

*Department of Biology- College of Science for Women-University of Baghdad 
Pavidrilidae; $\quad$ Dorydrillidae; Phreodrilidae and Propappidae. Species of Family Aeolosomatidae, may be treated as a separate class, Aphanononeura [2], which are relatively very small and transparent, characterize by the presence of hair chaetae in both dorsal and ventral bundles, ciliated prostomium and coloured epidermal glands with oil droplets. Septa between segments mostly absent [3].

Aquatic oligochaetes are usually small, ranging from $1 \mathrm{~mm}$ to a few centimeters in length and represent about athird of almost all valid species described to date, in addition, 4 of the 14 described megadriles families include species that occur in aquatic habitats. The microdriles are comprise 13 families which are fully aquatic, with the exception of the primarily terrestrial family Enchytraeidae, . Four families in the orders Tubificida and Lumbriculida are common in freshwater, the , Naididae, Lumbriculidae, and Enchytraeidae, in addition to the minor families, Pavidrilidae; Dorydrillidae; Phreodrilidae and Propappidae.

Naidid worms have been previously treated as a separate family Naididae [3\&4], but both morphological and molecular characters [5] support the premise that all members of the former clitellate family Naididae are phylogenetically nested within the former family Tubificidae. For this reason, Erèus \& Gustavsson [6] had proposed that these taxa together should be regarded as a single family to ovoid this paraphyly of Tubificidae suggesting that all Niadides were classified as members of Tubificidae. Ersèus et al. [7] submitted an application to the ICZN commission requesting to use its power to give precedence to Tubificidae, Vejdovesky 1876 over Naididae, Ehrenberg 1828. but the members of ICZN voted against it according to the International Code of Zoological Nomenclature, priority principles, since, the familygroup name Naididae is older than Tubificidae. [8]. The new family Naididae comprise two groups of worms, the naidid worms, and tubifide naidid worms

Niadid worms are characterized by the presence of needle chaetae accompanied with hair chaetae in the dorsal bundles [3;4 \& 9]. Timm \& Grimm [10] indicated that Homochaeta , although formally a valid species, might not exist in the nature. The original description of the nominal genus Homochaeta ,Bretscher,1896, based on different immature Naididae or Tubificidae. No type of material existed while all subsequent material proved to be misidentified. Neonais were considered as a doubtful genus resemble Uncinais by Brinkhurst \& Jameison[3].

According to [3], species of subfamily Pristininae were regarded as one genus( Pristina), of family Naididae, while [4] excluded Pristina from family Naididae and assigned it to new family Pristinidae as recommend by [12], with two subgenera , Pristina ( pristine) include 21 species with proboscis \&Pristina( Pristinella), with 7 species, without proboscis, In the members of this subfamily, the dorsal bundles start in II as in tubificid worm, so for this reason, Envall [12] classified them with subfamily Rhyacodrilinae.

Tubificid worms, probably are the best known of the freshwater oligochaetes. They are most commonly found in soft sediments rich in organic matter, and several species characteristically live in sites that receive organic pollution. Like all aquatic oligochaetes, tubificids respire cutaneously, but a unique feature of this family is that some species can tolerate anoxic conditions. This group 
consist of subfamilies, Tubificinae , Rhyacodrilinae, Phallodrilinae ,Limnodriloidinae, and Telmatodrilinae [8].

Enchytraeids are semi-aquatic worms, common in marginal aquatic habitats as marshes, small streams, springs, and interstitial waters along the margins of streams, and they are found occasionally in the sediments of lakes and rivers as well [4].

Species of family Lumbriculidae has rather uniform external appearance, but with highly diverse internal anatomy, particularly the reproductive system. Some of the commonest species have also reliable external characters, whereas others can be identified only on the basis of internal details [3].

Sampling techniques

Sampling freshwater oligochaetes for identification in Iraq is recommended during The period from February to John, where the most individuals are sexually mature. Tubificid, Lumbriculidae and other oligochaetes which live in the sediments can be collected with other macroinvertebrates when sampling freshwater zoobenthos, using varies net or bottom sampler, grabs or dredges. Large worms can easily sorted from sieving residue, in the field by spreading the sediment on a white tray. A magnification hand lens may be convenient for this purpose. The smaller mieobenthos form, like Naidi worms, can get lost in macroscopical sorting, but they are well visible under a low power dissecting microscope. Small part of sediment, together with aquatic plants placed in small aquarium, supplied with oxygen by small air pump. The settled sediment on the floor of aquarium can be collected with care by fine dropper and transfere to petridish of $10 \mathrm{~cm}$. diameter, then the worms can be sorted carefully under dissecting microscope . Enchytraeidae and other small oligochaetes, may be obtained by using the wet-funnel method recommended by [13]

Preservation and Mounting

Identification of some oligochaetes is most effective alive, so that the worm is easily detected through its movement and when all tissues are more or less transparent and the internal organs can be easily observed, especially for Enchytraeidae , which should be studied a live ever possible as they have not too many external identification characters [4]. Worms can be easily anesthetized by drops of carbonized drinking water.

The worms may be killed and preserved in $70 \%$ alcohol. Some species such as Branchuira sowerbyi and other, tend to fragments in alcohol, so this must be narcotized in $5 \%$ magnesium chloride before preservation [14]. Preserved worms stored in $70 \%$ alcohol or, $4 \%$ formalin. In temporary mount, glycerin can used as a clearing media [13 \&4]. It is reasonable to soak worms in glycerin for several hours or days before mounting under a cover slide. As glycerin makes the worm soft, and so it is possible to flattened them by exerting slight pressure on the cover slides. For better exposition of setae and some other details, Amman's lactophenol was recommended by [14], in which phenol ( carbolic acid) and lactic acid added to glycerol. The worms should be covered with cover slip and left in this fluid at least for several hours before examination.

For permanent preparation, Amman's lactophenol can be replaced by polyvinyl lactophenol [14], When this has dried sufficiently the preparation should be ringed, preferably by glyceel. Permanent mount can be also made by Canada balsam or other synthetic resin [15], Balsam makes chaetae even slightly transparent, on 
the other hand, several internal organs can be well visible.

Identification Criteria

The megadrilus worms, or the earthworms, can be identified without any mounting. Mature specimens of Glossoscolecidae and Lumbricidae, may be identified using only a lowpower stereoscopic microscope.

Naididae species are easy to identified by their external morphological characters such as chaetae, proboscis, presence of dermal papillae and gills. The chaetae are considered as a very important feature for the identification of genera and species, including the segment on which dorsal chaetae commence, the number of chaetae per bundle, relative sizes of teeth of bifid chaetae, and presence or absence of hair chaetae. Dorsal setae of Pristinae and Tubifinae always beginning from II while in species of Naidinae the dorsal chaetae beginning in sements further than II ( usually IV, V or VI). Hair setae present or absent in Tubifid worms, accordingly, their presence is useful in identifying species, but not genus. Their number generally range from 1-5 per bundle. There is neither Proboscis nor eyes in tubifcid species. [3 \& 4].

Setae present in most species of Enchytaeidae, but may be entirely absent in genus Achaeta . setal follicles are found in some species of Achaeta as ovoid or spherical structures, which are believed to occupy the site of former setae [13]. All other Enchytraeid species are characterized by the presence of short, simple pointed in variable shape, number, and arrangement. They may be sigmoid, slightly sigmoid, straight or irregularly bent They may be arranged in unilateral fan-like bundles, or in symmetrical bundles, with or without nodules [3 \& 4].

Species of family Lumbriculidae has rather uniform external appearance, their setae two per bundle, beginning from II, sigmoid and nodulated, no hair setae or modified genital setae. Setae may be simple pointed as in Rhynchelmis limosella, or bifid with short or reduced upper tooth. The angle between upper and lower tooth is usufull for identifying species. In Lumbriculus variegates, the upper tooth diverging at about $30^{\circ}$, where in Stylodrilus heringianus, with tiny upper tooth almost parallel to lower one, seldom some anterior setae also simple pointed [3 \& 4].

\section{Result and Discussion:}

A total of 62 species were recorded by many investigators in TigrisEuphrates basin in Iraq, 39 species in River Tigris; 41 species in River Euphrates and 34 species in southern marshes and Shutt al-Arab ( Table 1).

Four species of Aelosomatidae were recorded, including Aeolosoma aquaternarium, and A. Leidyi recorded by [16] While A.variegatum and $A$. hemprichi by [17] in River Euphrates.

A total of 54 species of Family Naididae were recorded in Iraq (31 Naidinae, 8 Pristininae \& 15 tubificid worms), in addition to Lumbriculus variegates and Eiseniella tetraedra ( Table 1), by many investigators $[18 ; 19$ ;20; 21;22; 23, 24; 25; 26, 27; 28; 29]. The most abundant species in Iraqi water are Nais variabilis, Stylaria lucastris ( Naidinae), Pristina longiseta ( Pristininae), Branchuira sowerbyi and Limnodrilus hoffmeisteri ( Tubificid worms) . 
Table (1): Aquatic Oligochaete species from Tigris-Euphrates basin/ Iraq

\begin{tabular}{|c|c|c|c|c|}
\hline Family \& Subfamily & species & $\begin{array}{c}\mathrm{R} \text {. } \\
\text { Euphrates. }\end{array}$ & $\begin{array}{c}\text { R. } \\
\text { Tigris }\end{array}$ & $\begin{array}{l}\text { Southern marshes \& } \\
\text { shutt al-Arab }\end{array}$ \\
\hline \multirow{4}{*}{ Aeolosomatidae } & Aeolosoma aquaternarium Piguet, 1906 & - & + & - \\
\hline & A. $\quad$ Leidyi Cragin, 1887 & - & + & - \\
\hline & Variegatum Vejdovsky 1884 & + & - & - \\
\hline & hemprichi Ehrenberg 1828 & + & - & - \\
\hline \multirow{31}{*}{ Naididae Naidinae } & $\begin{array}{l}\text { Chaetogaster cristallinus } \\
\text { Vojdovsky, } 1883\end{array}$ & - & + & - \\
\hline & C.limnaei von Baer, 1827 & + & + & + \\
\hline & C.langi Bretscher, 1896 & - & + & - \\
\hline & C.diastrophus (Gruithuisen, 1828) & + & + & - \\
\hline & C.diaphanus (Gruithuisen, 1828) & - & + & - \\
\hline & Paranais litoralis ( Müller,1784) & + & - & + \\
\hline & $P$. frici Hrabe, 1941 & + & - & + \\
\hline & $\begin{array}{c}\text { Stephensoniana trivandrana } \\
\text { ( Aiyer,1926) }\end{array}$ & + & - & - \\
\hline & Ophidonais serpentina ( Müller,1773) & + & + & - \\
\hline & Slavina appendiculata d'Udekem, 1885 & + & + & + \\
\hline & S. isochaeta Cernovitov, 1939 & + & + & - \\
\hline & Specaria josinae (Vojdovsky,1883) & + & - & - \\
\hline & Stylaria lacustris ( Linnaeus, 1767) & + & + & + \\
\hline & S.fossularis Leidy, 1852 & + & + & + \\
\hline & Dero ( Dero) digitata ( Müller,1773) & - & + & + \\
\hline & D. dorsalis Forroniere, 1899 & - & + & + \\
\hline & D. obtusa d`Udekem, 1855 & - & + & + \\
\hline & D. nivea Aiyer, 1929 & + & - & + \\
\hline & D. evelinae Marcus, 1943 & + & - & - \\
\hline & Dero (Aulophorus)furcata (Müller,1773) & + & - & + \\
\hline & $D(A)$ indicus Naidu, 1962 & + & - & - \\
\hline & Allonais inaequalis (Stephenson, 1911) & + & + & - \\
\hline & A. gwalioransis & - & - & + \\
\hline & A. pectinata (Stephenson, 1910) & - & - & + \\
\hline & Nais variabilis Piguet, 1906 & + & + & + \\
\hline & N. elinguis Müller, 1773 & + & + & + \\
\hline & N.Stolci (Hrabe, 1981) & + & + & - \\
\hline & N.pardalis Piguet, 1906 & + & + & + \\
\hline & N. simplex Piguet, 1906 & + & + & - \\
\hline & N.pseudobtusa Piguet, 1906 & + & + & - \\
\hline & N. communis Piguet, 1906 & - & + & + \\
\hline \multirow{8}{*}{ Naididae Pristininae } & Pristina longiseta Ehrenberg, 1828 & + & + & + \\
\hline & P. macrochaeta Stephenson . 1931 & - & - & + \\
\hline & P. aequiseta Bourne, 1891 & + & + & + \\
\hline & P. foreli Piguet, 1906 & + & + & - \\
\hline & P. proboscida Beddard, 1896 & & + & - \\
\hline & Pristinella osborni (Walton, 1906) & + & - & + \\
\hline & P. sima (Marcus, 1944) & + & - & + \\
\hline & $P$. jenkinae $($ Stephenson, 1931$)$ & - & + & - \\
\hline \multirow{15}{*}{$\begin{array}{l}\text { Naididae , Tubificid } \\
\text { worms }\end{array}$} & Embolocephalus velutinus ( Grube, 1879) & - & - & + \\
\hline & Aulodrilus pigueti Kowalewski, 1914 & + & - & + \\
\hline & Branchuira sowerbyi ( Beddard, 1892) & + & + & + \\
\hline & $\begin{array}{c}\text { Psammoryctides moravicus (Hrabe, } \\
1934 \text { ) }\end{array}$ & & + & - \\
\hline & Peloscolex tenuis Hrabe, 1931 & + & & - \\
\hline & Tubifex tubifex (Müller,1774) & + & + & + \\
\hline & $\begin{array}{c}\text { Potamothrix hammoniensis } \\
\text { (Michaelsen, 1901) }\end{array}$ & + & + & - \\
\hline & P. bavaricus ( Oschmann. 1913) & & + & - \\
\hline & $\begin{array}{c}\text { Rhyacodrilus coccineus( (Vedjdovsky, } \\
1875)\end{array}$ & + & + & - \\
\hline & Limnodrilus hoffmeisteri Claparéde, 1862 & + & + & + \\
\hline & L. claparadeanus Ratzel, 1868 & + & + & + \\
\hline & $\begin{array}{l}\text { L. maumeensis Brinkhurst and Cook, } \\
1966\end{array}$ & - & - & + \\
\hline & L. silvani Eisen, 1879 & - & + & - \\
\hline & L. udekemianus Claparéde, 1862 & - & + & - \\
\hline & L. profundicola ( Verrill, 1871) & + & + & + \\
\hline Lumbriculidae & Lumbriculus variegates & - & - & + \\
\hline \multirow[t]{2}{*}{ Lumbricidae } & Eiseniella tetraedra ( Savigny, 1826) & + & + & + \\
\hline & No. species & 39 & 40 & 32 \\
\hline
\end{tabular}

( +; presnt, - ; not present) 


\section{References:}

1. Martin, P; Martinez-Ansemil, E.; Pinder, A.; Timm, T.; and Wetzel, M.J. 2008. Global diversity of oligochaetous clitellates ( Oligochaeta : Clitellata ) . in: Freshwater animal diversity assessment. Development in Hydrobiology, 198 : 117- 127.

2. Timm, T. 1981. On the origin and evolution of aquatic oligochaeta. Esti NSV Teuduste Akademia Toimetised Biologia, 30: 174-181.

3. Brinkhurst, R.O. and Jameison, B.G.1971. Aquatic Oligochaetes of the world Univ. of Torontopress. Toronto, Canada. $859 \mathrm{pp}$

4. Timm, T. 2009. Aguide to the freshwater Oligochaeta and Polychaeta of Northern and Central Europe. Lauterbornia, 66: 1- 235.

5. Christensen, B. and Thiesen, B.F. 1998. Phylogenetic status of the family Naididae (Oligochaeta, Annelida) as inferred from DNA analysis. JZSER, 36:169-172.

6. Erseus, C. and Gustarsson, L.2002. Aproposal to regard the former family Naididae as a subfamily within Tubificidae (Annelida, Clitellata). Hydrobiologia, 485: 253- 256.

7. Erseus, C. 2005. Tubificidae Vejdovsky, 1876 (Annelida, Clitellata): proposed precedence over Naididae Ehrenberg, 1828. Bull. Zool. Nomencl., 62(4): 226 231.

8. Erseus, C.; Wetzel , M.J. and Gustavsson, L. 2008. ICZN rulesa farewell to Tubificidae (Annelida, Clitellata). Zootaxa, 1744: 66- 68.

9. Pinder, A.2010. Tools for identifying selected Australian aquatic Oligochaetes (Clitellata: Annelida). Museum Victoria Science Reports. 13: 1- 26.

10. Timm, T. and Grimm, R. 2005. What is Homochaeta naidina Brestcher, 1896. ( Annelida,
Oligochaeta , Naididae ). Zoosystema 27(3): 469-482.

11. Envall, I.; Källersjö, M.; and Ersěus, C. 2006. Molecular evidence for non-monophyletic status of Naididae ( Annelida, Clitellata, Tubificidae ). Molecular phytogenetics and evolution, 40: 570-584.

12. Envall, I. 2009. Evolutionary Perspective on Naidinae (Annelida, Clitellata, Naididae):Molecular and Morphological Revelations. Ph.D. thesis, Stockholms Univ.,48 pp.

13. Nielson, C.O. and Christensen, B. 1959. The Enchytraeidae , Critical revision and taxonomy of European species. (Studies on Enchytraeidae VII ) . Natura Jutlandica, 8-9 : 1160. ( Naturhistorisk Museum ) Aarhus, Danemark.

14. Brinkhurst, R.O. 1963. A Guide for the identification of British aquatic oligochaeta. Freshwater Biological Association. Sci. publ. No. 22

15. Beylich, A. 2005. A method for preservation and mounting of Enchytraeidae (Oligochaeta: annelid) . Proceeding of the Estonian Academy of Sciences. Biology. Ecology. 54(4): 352-355.

16. Radhi, M. M. 2012, Sorting and Identification of Naididae species nnelida- Oligochaeta) from Different aquatic sites within Baghdad city. MSc. Thesis, College of Science for Women, University of Baghdad.

17. Al- Janabi, E.O. 2012. Study of Aquatic Oligochaetes community in the Euphrates River in AlMussayab / Iraq. MSc theses. College of Science for Women, Univ. of Baghdad.

18. Al-Jaboiry, A.M.A. 2012 An identification stydy on subfamily Tubificinae ( Oligochaeta: Naididae) from different aquatic habitat in Baghdad/Iraq. MSc. 
Thesis, College of Science for Women, Univ. of Baghdad/ Iraq.

19. Jaweir, H.J 2011. Anew record of three tubificid species (Annelida: Oligochaeta) from AL - Hawiezah marsh, Iraq. Mesopot. J. Mar. Sci. , 26(2): $114-121$.

20. Jaweir, H.J. and Rhadi. M.M. 2013: Naididae ( Clitellata: Oligochaeta and Aeolosomatidae ( Polychaeta: Aphanoneura) species associated with aquatic plants in River Tigris / Baghdad / Iraq. J. Baghdad for Sci., 10(1):116-

21. Jaweir, H.J. and Alwan, A.M. 2013. Sludge worms species ( Oligochaeta: Naididae: Tubificinae) from different aquatic habitat in Baghdad/ Iraq. J. Baghdad for Sci. 10(2): 269- 280

22. Jaweir, H.J. and Al-Janabi, E.O.S. 2012. Biodiversity and abundance of aquatic oligochaetees family Naididae in the middle sector of Euphrares river, city/ Iraq. The International Journal of the Environment and Water,1 (1):122130

23. Jaweir, H.J.; Sabtie, H.A. and Almukhtar, E. A. 2012. Aquatic Oligochaetes of Iraq's Southern Marshes. J. Baghdad for Sci., 9(3): 472- 480.

24. Ali, L.A. 2007. A study of macroinvertebrates community in the middle sector of Greater Zab
River/Iraq. Ph.D. thesis, College of Science for Women, Univ. of Baghdad. Iraq

25. Sabtie, H.A. 2009. An ecological study of the benthic macroinvertebrate community in the Southern Marshes of Iraq. Ph.D. thesis, Colloge of Science for Women, Univ. of Baghdad. Iraq

26. AL -Abbad, M.Y.2010. New records of Pristina proboscidea and P.aquiseta (Oligochaeta: Naididae) from Iraq. Marsh Bulletin, 5(2): 132- 142.

27. AL -Abbad, M.Y.M. 2012. New records of twelve species of Oligochaeta (Naididae and Aeolosomatidae) from the Southern Iraqi Marshes, Iraq. JJBS., 5(1) : 31 -36 .

28. AL -Abbad, M.Y.M. and AL Mayah, S.H. 2010. New records of two species of Oligochaetes (Naididae): Pristina longiseta and $P$. macrochaeta from Iraq, with notes on their morphology and reproduction. Mesopot. J. Mar. Sci., 25(2): $57-66$.

29. Nashaat, M.R. 2010. Impact of AL-Durah Power Plant effluents on Physical, chemical and invertebrates biodiversity in Tigris River Southern Baghdad. Ph. D. thesis, College of Science, Univ of Baghdad. 


\title{
قائمة بانواع قليلة الاهلاب المائية في حوض دجلة والفرات
}

\section{هيفاء جواد جويرث}

\author{
*قسم علوم الحياة - كلبة العلوم للبنات / جامعة بغداد
}

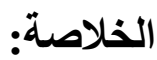

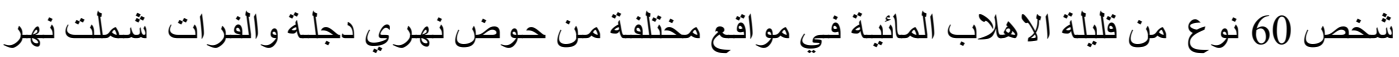

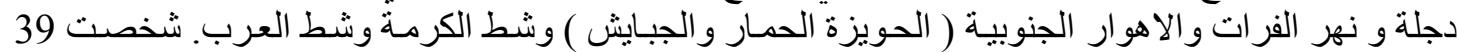

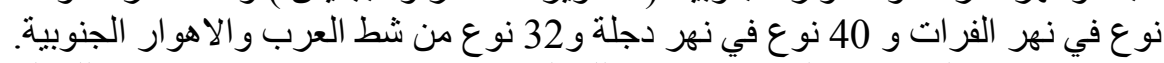

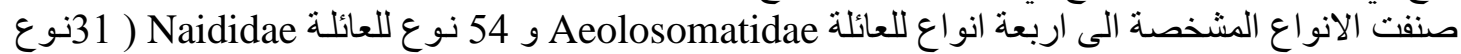

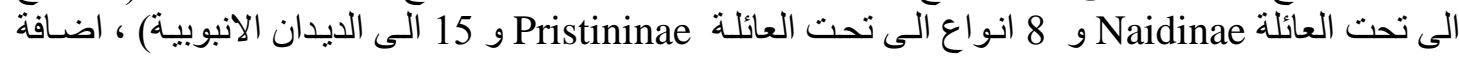

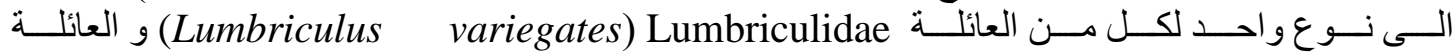

.(Eiseiella tetraedra)Lumbricidae

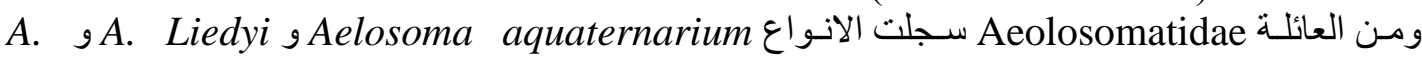

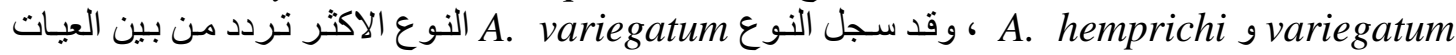

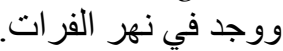

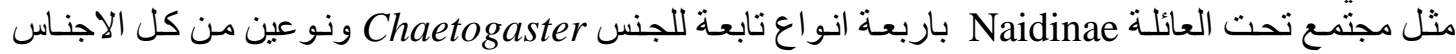

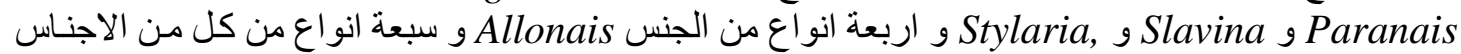

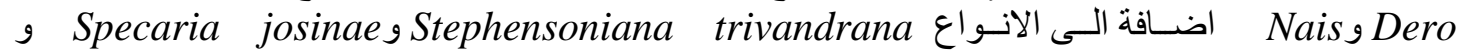

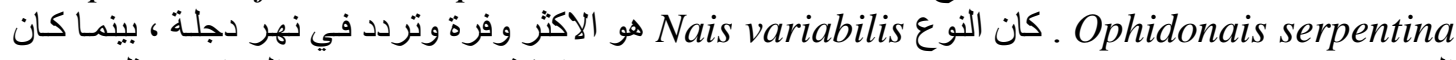

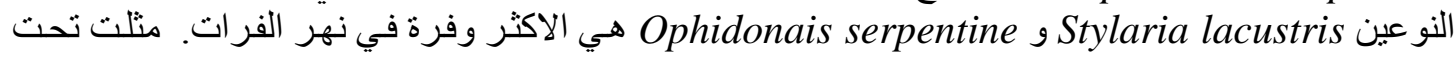

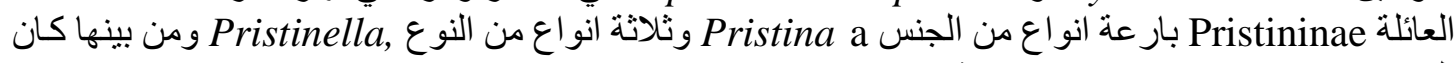

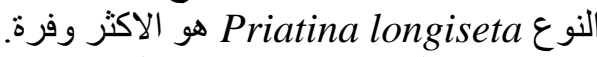

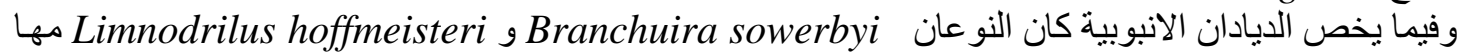

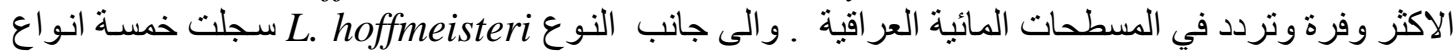
اخرى تابعة للجنس Limnodrilus ونو عين من الجنس Potomothrix و الانو اع المفردة Lothex tubifex وPsammoryctides moravicus و Aulodrilus piguetiagEmbolocephalus velutinus .Rhyacodrilus coccineus 